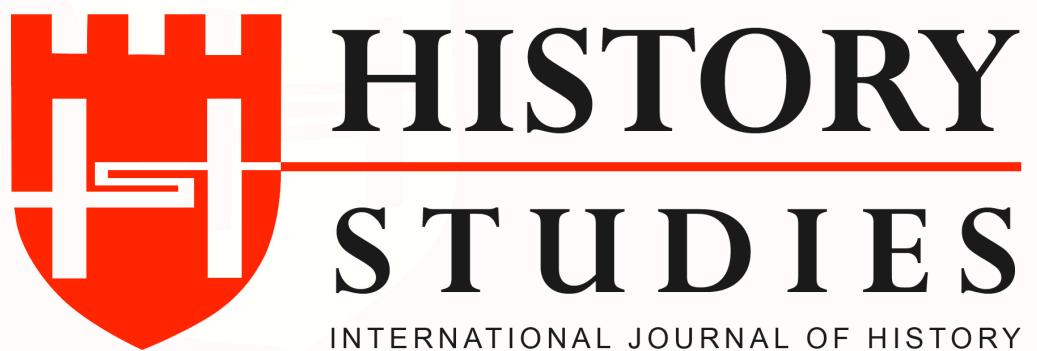

\author{
ISSN: 13094173 (Online) 1309 - 4688 (Print) \\ Volume 11 Issue 6, December 2019 \\ DOI Number: 10.9737/hist.2019.796 \\ Araştırma Makalesi
}

Makalenin Geliş Tarihi: 22.03.2019 Kabul Tarihi: 04.11.2019

Atıf Künyesi: Behçet Kemal Yeşilbursa, "Proposals for a Settlement of the Cyprus Problem according to British Documents (1954-1974)", History Studies, 11/6, Aralık 2019, s. 1985-2002.

\title{
PROPOSALS FOR A SETTLEMENT OF THE CYPRUS PROBLEM ACCORDING TO BRITISH DOCUMENTS (1954-1974)
}

\author{
İngiliz Belgelerine Göre Kıbrıs Sorununun Çözümü İçin Öneriler \\ (1954-1974)
}

\author{
Prof. Dr. Behçet Kemal Yeşilbursa \\ ORCID No: 0000-0001-6309-5703 \\ Uludağ University
}

\begin{abstract}
During the early 1950s, the demand for a union with Greece (Enosis) grew stronger among the Greek Cypriot population of Cyprus under the leadership of Archbishop Makarios. The Greek Government raised the issue at the United Nations General Assembly in September 1954, but their demand for self-determination for Cyprus was not adopted. The British Government continued to treat the issue as an internal matter, but the outbreak of an armed Greek Cypriot uprising in Cyprus on 1 April 1955, under the leadership of pro-Enosis Colonel Grivas, led the British Government to call a conference in London on the Cyprus problem in September 1955. Greece and Turkey were invited to attend on behalf of their respective minorities in Cyprus, but there was no representation of the Cypriots themselves. From 1955 to 1974, a series of multilateral talks were held at intervals: bilateral between Turkey and Greece, trilateral between Britain, Turkey and Greece, and inter-communal between Greek and Turkish Cypriots. However, they failed to reach a settlement on the future constitutional arrangements in Cyprus, and the dialogue was consequently suspended. The first tripartite talks on the Cyprus issue were held in London from 29 August to 7 September 1955. Direct Anglo-Cypriot negotiations took place in Cyprus from October 1955 to February 1956. In January 1958, the "Foot Plan" was presented to the British Prime Minister by Sir Hugh Foot. The "Macmillan Plan" was announced in the House of Commons by the British Prime Minister in June 1958. In 1964, representatives of Britain, Turkey, Greece and both Cypriot communities met in London, but the Conference ended in deadlock two weeks later, because the views of the Greek and Turkish Cypriots proved to be irreconcilable. In July 1964, the "Acheson Plan" was introduced, but rejected by the Greeks. In May 1966, the Greek and Turkish Governments began a series of secret exchanges on the relations between their two countries with particular reference to the Cyprus issue. However, nothing emerged. In June 1966, the British Government announced the formation of a commission under Lord Radcliffe and presented the Turks with a plan centred on arranging a date for self-determination to be applied, with certain guarantees for the Turkish Cypriot minority. Intercommunal talks started in June 1968 and continued, with intervals, until 1974 without any success.
\end{abstract}

Key words: Turkey, Greece, Britain, Cyprus

Özet

1951-1954 y1lları arasında Yunanistan ile olan bir birlik talebi (Enosis), Kıbrıs Rumları arasında, Başpiskopos Makarios önderliğinde, o sırada İngiliz Kraliyet Kolonisi olan, Kıbrıs’ta güç kazandı. Eylül 1954'te Yunan Hükümeti, konuyu Birleşmiş Milletler Genel Kurulunda gündeme getirerek resmen sahiplendi. Ancak, Kıbrıs için kendi kaderini tayin hakkını talep eden Birleşmiş Milletler

\section{History Studies}


kararını kabul etmedi. İngiliz Hükümeti konuyu bir iç mesele olarak ele almaya devam etti. Ancak Albay Grivas'ın önderliğindeki Kıbrılıların Millî Mücadele Örgütü (EOKA) 1 Nisan 1955'te Kıbrıs'ta silahlı bir ayaklanmasının patlak vermesine yol açtı. Bunun üzerine İngiliz Hükümeti Londra'da Eylül $1955^{\prime}$ te Kıbrıs sorununu görüşmek için bir konferans toplamaya karar verdi. Yunanistan ve Türkiye bu konferansa Kıbrıs'taki kendi azınlıkları adına davet edildi. Fakat Kıbrıslıların kendileri davet edilmedi. 1955-1974 yılları arasında, Türkiye ile Yunanistan arasında ikili, İngiltere, Türkiye ve Yunanistan arasında üç taraflı ve Kıbrıslı Rumlar ile Kıbrıslı Türkler arasında toplumlararası olmak üzere bir dizi çok taraflı görüşmeler yapıldı. Bu görüşmeler sonucunda 1960'da Kıbrıs Cumhuriyeti kuruldu. Ancak cumhuriyet çok fazla yaşamadı ve 1963'te yıkıldı. 1964'te İngiltere, Türkiye, Yunanistan ve her iki Kıbrıs toplumunun temsilcileri Londra'da bir araya geldi. Fakat görüşmeler ancak iki hafta sürdü. Çünkü Kıbrıslı Rumların ve Türklerin görüşleri birbirinden oldukça uzaktı. Mayıs 1966'da Türk ve Yunan Hükümetleri iki ülke arasındaki ilişkiler ve Kıbrıs sorununun çözümü konusunda bir dizi gizli görüşme yaptı. Ancak bu görüşmelerden de hiçbir sonuç çıkmadi.

Anahtar kelimeler: Türkiye, Yunanistan, İngiltere, Kıbrıs

\section{Introduction}

Between 1951 and 1954, the demand for Enosis (union with Greece) grew among the Greek Cypriot population of Cyprus, then a British Crown Colony, under the leadership of Archbishop Makarios. ${ }^{1}$ The Greek Government formally embraced their cause in September 1954 when they raised the issue at the United Nations General Assembly; however, its resolution demanding self-determination for Cyprus was not adopted. The British Government continued to regard the matter as a domestic issue. However, the armed Greek Cypriot uprising in Cyprus on 1 April 1955, under the leadership of Colonel Grivas and his pro-Enosis National Organisation of Cypriot Fighters (EOKA), pushed the British Government to call a conference in London on the Cyprus problem in September 1955. Greece and Turkey were invited to attend this conference on behalf of their respective minorities in Cyprus, but there was no Cypriot representation. ${ }^{2}$

\section{The Tripartite Conference (29 August - 7 September 1955, London)}

Preliminary discussions at the Tripartite Conference centred on the crucial issues of selfdetermination and self-government.

\section{1. Self-determination}

a) Greek views: Greece wanted an immediate formal recognition of the principle of selfdetermination. If this resulted in Enosis, provision was to be made for safeguarding the rights of the Turkish Cypriot minority.

b) Turkish views: The Turks were opposed to the principle of self-determination in its application to Cyprus, because of the position of the Turkish Cypriot minority.

c) British views: The British Government also opposed the application of the principle of self-determination to Cyprus, "in view of geographical, traditional, historical, strategical and other considerations."

\footnotetext{
${ }^{1}$ FCO51/353/RR5/15, “A History of proposals for a settlement of the Cyprus problem, 1955-1974”, Research Department Memorandum, 14.12.1974. See FCO9/RK1011/1, Turkey: Annual Review for 1954.

2 FCO51/353/RR5/15, "A History of proposals for a settlement of the Cyprus problem, 1955-1974", Research Department Memorandum, 14.12.1974. Baskın Oran (ed.), Türk Dış Politikası, Cilt-I: 1919-1980, İletişim Yayınları, İstanbul, 2003, p. 593-614. See FO371/123999, Annual Review for 1955.

${ }^{3}$ FCO51/353/RR5/15, “A History of proposals for a settlement of the Cyprus problem, 1955-1974”, Research Department Memorandum, 14.12.1974. Faruk Sönmezoğlu, Tarafların Tutum ve Tezleri Açısından Kıbrıs Sorunu (1945-1986), İÜ İktisat Fakültesi Yayınları, İstanbul, 1991, Passim. See FO371/123999, Annual Review for 1955.
} 


\section{2. Self-Government}

a) Greek views: Greece favoured the introduction of self-government, on the condition that this would eventually lead to self-determination within a reasonable period of time.

b) Turkish views: Turkey agreed in principle but opposed the introduction of selfgovernment as an immediate prospect, because it viewed the political atmosphere in Cyprus at that time as unsuited to self-government. Should conditions become more favourable to selfgovernment, the Turks would only accept this if sufficient guarantees were provided for the Turkish Cypriot community.

c) British views: Britain was fully in favour of establishing self-government and presented new constitutional proposals to establish it. However, only internal self-government was foreseen. ${ }^{4}$

Following discussions on these matters, on 6 September the British Government 1955, presented its constitutional proposals, the main points of which were as follows:

a) The Constitution would provide for an Assembly with an elected majority a proportionate quota of seats (numbers unspecified) being reserved for the Turkish community.

b) All Departments of the Cyprus Government would be progressively transferred to Cypriot Ministers, responsible to the Assembly, with the exception of Foreign Affairs, Defence and Public Security, which would be reserved to the Governor.

c) There would be proper safeguards for the integrity and independence of the Public Service. As part of the safeguards to be provided for the Turkish community, a proportion of the Ministerial portfolios would be reserved for that community.

d) A Cypriot Chief Minister to head the new Cypriot administration would be chosen by the Assembly with the approval of the Governor.

e) A special Tripartite Committee, with Greek, Turkish and British representatives, should be set up in London to work out the full details of the new constitution and to serve as a standing instrument of consultation between the three governments.

f) As far as self-determination was concerned, since the three governments could not reach agreement, the British Government proposed that the issue be set aside, and not allowed to hinder the establishment of self-government. ${ }^{5}$

The conference drew to an end on 7 September 1955, in the midst of anti-Greek riots in Istanbul and Izmir. The British Government's proposals were formally rejected on 17 September by the Greek Government, who claimed that the constitution was inadequate for so "highly developed and civilised a people as the Cypriots." The failure to make any progress on the issue of self-determination was also cited as a reason for the Greek Government's rejection of the British proposals. The Turkish Government also rejected the proposals, claiming that, as

\footnotetext{
${ }^{4}$ FCO51/353/RR5/15, “A History of proposals for a settlement of the Cyprus problem, 1955-1974”, Research Department Memorandum, 14.12.1974. Sönmezoğlu, Tarafların, Passim. See FO371/123999, Annual Review for 1955.

5 FCO51/353/RR5/15, “A History of proposals for a settlement of the Cyprus problem, 1955-1974”, Research Department Memorandum, 14.12.1974. Sönmezoğlu, Tarafların, Passim. See FO371/123999, Annual Review for 1955.

${ }^{6}$ FCO51/353/RR5/15, “A History of proposals for a settlement of the Cyprus problem, 1955-1974”, Research Department Memorandum, 14.12.1974. Sönmezoğlu, Tarafların, Passim. See FO371/123999, Annual Review for 1955.
} 
long as the Greeks insisted on self-determination as an alleged reason for annexing the island, and as long as terrorism and antagonism continued to exist among the island communities, selfgovernment would only lead to further deterioration of the situation both in the island and internationally. ${ }^{7}$

\section{Direct Anglo-Cypriot Negotiations (The Talks between the British Governor Field Marshal Sir John Harding and Archbishop Makarios, October 1955-February 1956)}

On 4 October 1955, the second day in his position as the new British Governor, Field Marshal Sir John Harding commenced negotiations with Archbishop Makarios, which were to continue until their final breakdown in February 1956. The position of the British Government initially was that which it had adopted in the Tripartite Conference in London. Makarios, on the other hand, made it clear that the recognition of self-determination (with no fixed date set for its application) constituted the indispensable prerequisite for any co-operation. ${ }^{8}$ Consequently the talks broke down by the middle of October, pushing the British Government to introduce an alternative formula:

"It is not our position that the principle of self-determination can never be applicable to Cyprus. It is our position that it is not now a practical proposition both on account of the present strategic importance of the island and on account of the consequences on relations between NATO powers in the Eastern Mediterranean." Moreover, once self-government, as proposed by the British Government's constitutional proposals, had been established and had proved itself to be operational and capable of safeguarding the interests of all elements of the Cypriot population, then the British Government would be prepared to discuss the future of the island with representatives of the Cypriots themselves, together with the Greek and Turkish Governments. ${ }^{10}$

While this formula modified the British Government's attitude toward self-determination in Cyprus that the Turkish Government had objected to, it did not satisfy the expectations of Greece and the Greek Cypriots. Hence, Archbishop Makarios rejected the formula, emphasising that self-determination was a necessity before self-government, and that the formula did not recognise the right of self-determination for the people of Cyprus. The Greek Government supported Makarios throughout the negotiations and did not submit to Britain's pressure to accept the formula. ${ }^{11}$

A subsequent revision of the British Government's formula was found by Archbishop Makarios to be more acceptable as a basis for co-operation in the introduction of a constitution and self-government. However, but by the end of February 1956 the talks had stalled over disagreements about the possible constitution and about amnesty proposals. ${ }^{12}$

\footnotetext{
7 FCO51/353/RR5/15, “A History of proposals for a settlement of the Cyprus problem, 1955-1974”, Research Department Memorandum, 14.12.1974. Cihat Göktepe, British Foreign Policy towards Turkey, 1959-1965, Frank Cass, London, 2003, p. 60-137.

${ }^{8}$ FCO51/353/RR5/15, "A History of proposals for a settlement of the Cyprus problem, 1955-1974", Research Department Memorandum, 14.12.1974. Göktepe, British, p. 60-137.

9 FCO51/353/RR5/15, "A History of proposals for a settlement of the Cyprus problem, 1955-1974", Research Department Memorandum, 14.12.1974.

10 FCO51/353/RR5/15, "A History of proposals for a settlement of the Cyprus problem, 1955-1974", Research Department Memorandum, 14.12.1974. Göktepe, British, p. 60-137.

11 FCO51/353/RR5/15, “A History of proposals for a settlement of the Cyprus problem, 1955-1974”, Research Department Memorandum, 14.12.1974. Ata Atun, Kıbris Anlaşmaları, Planlarl ve Önemli BM, AB Kararları (15711983), Cilt: I, Samtay Vakfi Yayınları, Mağusa, 2007, Passim.

12 FCO51/353/RR5/15, "A History of proposals for a settlement of the Cyprus problem, 1955-1974", Research Department Memorandum, 14.12.1974. Atun, Klbrls, Passim.
} 


\section{British Plan of June 1956}

In June 1966, the British Government presented to the Turks a plan aiming to fix a date when self-determination might be applied, with various guarantees and safeguards for the Turkish Cypriot minority. This plan embodied an attack on the Turkish argument that selfdetermination was not applicable to Cyprus and the Turks regarded it as a major concession to the Greeks and Enosists. They stated explicitly that they were resolutely opposed to any change in the international status of the island, and as a result, the British Government abandoned its plan. Eden made it clear in the British Parliament that the principle of self-determination had been accepted by the British Government, and that it was the issue of its application that was the main problem remaining, one which was irrevocably opposed by "our Turkish allies." 13

\section{The Radcliffe Commission (June - December 1956)}

In June 1956, following the abandonment of its plan for fixing the date of selfdetermination, the British Government announced the formation of a commission under Lord Radcliffe to consider the framework of a new liberal constitution for Cyprus, providing for selfgovernment, and protecting the interests of all communities in the island. Any recommendation and proposal made by the Commission was to relate to the management of Cyprus' internal affairs only. All matters pertaining to external affairs, defence and security were to remain the responsibility of the British Governor. The recommendations made by Lord Radcliffe were tabled in the British Parliament by the Colonial Secretary on 19 December $1956 .{ }^{14}$ The main points of the proposed constitution were:

\section{a) The Legislative Assembly}

The Greek Cypriots would have an effective majority in the Legislative Assembly, other than on issues affecting affairs of the Turkish community, where the consent of two thirds of the Turkish Cypriot members in the Chamber was to be required. The Assembly was to consist of a Speaker, a Deputy Speaker and 36 other members. Six members of the Assembly would be nominated by the Governor at his discretion. Six other members would be elected by votes on a Turkish Cypriot communal roll. The other 24 members would be elected by votes on a general roll, that is to say, on the Greek Cypriot roll, for the Turks would be excluded from the general roll. $^{15}$

\section{b) The Executive}

There would be a Cypriot Prime Minister as the head of government in self-governing matters. He would be appointed by the Governor, but it would be the duty of the Governor to select the person who seemed to have the general support of the Assembly. The Governor, on the recommendations of the Prime Minister would also appoint the other ministers. There would also be a Turkish minister in the cabinet "ex officio". He was to be the head of an office for Turkish Cypriot affairs, with its own budget. ${ }^{16}$

\footnotetext{
${ }^{13}$ FCO51/353/RR5/15, “A History of proposals for a settlement of the Cyprus problem, 1955-1974”, Research Department Memorandum, 14.12.1974. Atun, Klbrls, Passim. See FO371/130174, Turkey: Annual Review for 1956. 14 FCO51/353/RR5/15, “A History of proposals for a settlement of the Cyprus problem, 1955-1974", Research Department Memorandum, 14.12.1974. Göktepe, British, p. 60-137. See FO371/130174, Turkey: Annual Review for 1956.

${ }^{15}$ FCO51/353/RR5/15, “A History of proposals for a settlement of the Cyprus problem, 1955-1974”, Research Department Memorandum, 14.12.1974. See FO371/130174, Turkey: Annual Review for 1956.

${ }^{16}$ FCO51/353/RR5/15, "A History of proposals for a settlement of the Cyprus problem, 1955-1974", Research Department Memorandum, 14.12.1974. See FO371/130174, Turkey: Annual Review for 1956.
} 


\section{c) The Governor}

The Governor would be responsible for external affairs, the defence of Cyprus, and internal security. In these matters he would retain the power of law-making and the conduct of all aspects of the executive administration. In addition, no bill passed by the Legislative Assembly could be valid as law unless the Governor had signified his assent. In all other matters lying within the field of self-governing matters, the Governor would have the duty of a constitutional head of government. ${ }^{17}$

\section{d) The Judiciary}

A Supreme Court would have jurisdiction in all proceedings in which the validity of any law of the Assembly was called into question as violating the provisions of the constitution which restricted the legislative power of the Assembly. The Supreme Court would comprise a president (Chief Justice) and two other judges - one Greek and one Turkish. The Chief Justice, who must not be a Cypriot citizen, would be appointed by the Governor at his discretion but after consultation with the Prime Minister. Respectively, the other two judges would be appointed also by the Governor after consultation with the Chief Justice. In case the Legislative Assembly increased the number of judges, it was provided that there would always be an equal number of Greeks and Turks. Another court called the "Tribunal of Guarantees" would also be established, mainly in order to protect individual rights guaranteed by the Constitution. The members of this court would also be appointed by the Governor after consultation with the Prime Minister and the Chief Justice. ${ }^{18}$

The Greek Government published their response to the Radcliffe proposal on 19 December 1956, before there had been any reference either to the Archbishop or the Cypriots. It rejected the proposals because they did not provide for self-determination, and therefore conflicted with the basic principles of the UN charter. It objected that the proposals were neither democratic nor liberal, because the unlimited powers given to the Governor limited the application of the principle of majority rule which it introduced. The Turkish Government, on the other hand, stated that it considered that the Radcliffe Report would constitute a reasonable basis for discussion. ${ }^{19}$

\section{The Foot Plan (December 1957-January 1958)}

Sir Hugh Foot was appointed to replace Field Marshal Sir John Harding in October 1957. This led to a new assessment of the situation and new proposals for a settlement were presented to the Prime Minister by Foot on 1 January $1956 .{ }^{20}$ The main points of Foot's recommendations were:

a) The reaffirmation of the British Government's acceptance of the principle of selfdetermination, and an announcement of the British Government's intention to achieve a settlement of the Cyprus problem on the basis of that principle, 7 years after the end of the state of emergency.

\footnotetext{
${ }^{17}$ FCO51/353/RR5/15, “A History of proposals for a settlement of the Cyprus problem, 1955-1974”, Research Department Memorandum, 14.12.1974. See FO371/130174, Turkey: Annual Review for 1956.

18 FCO51/353/RR5/15, “A History of proposals for a settlement of the Cyprus problem, 1955-1974", Research Department Memorandum, 14.12.1974. See FO371/130174, Turkey: Annual Review for 1956.

19 FCO51/353/RR5/15, "A History of proposals for a settlement of the Cyprus problem, 1955-1974", Research Department Memorandum, 14.12.1974. Göktepe, British, p. 60-137.

${ }^{20}$ FCO51/353/RR5/15, "A History of proposals for a settlement of the Cyprus problem, 1955-1974", Research Department Memorandum, 14.12.1974. Sönmezoğlu, Tarafların, p. 15-55.
} 
b) During the seven-year period the people of Cyprus should show that they were ready to work and maintain a representative constitution. Discussions as to the form of that constitution would be undertaken in the first instance with the Governor in Cyprus.

c) The Turkish Cypriots, no less than the Greek Cypriots should be given the right of selfdetermination as a community, and should decide their own future status.

d) If at any time a solution for the future of the island was reached which was approved by the Greek and Turkish Governments and the Greek and Turkish communities in Cyprus, the British Government would accept it, provided that it did not affect the retention by the British Government of such bases and installation as might be required to meet the strategic requirements of Britain and its allies.

e) Abolition of the State of Emergency within 3 months, and return to the island of Archbishop Makarios. ${ }^{21}$

The Foot Plan contained a possibility that had previously been foreseen by Lennox Boyd, Colonial Secretary, when he declared that the operation of self-determination in a mixed population must include partition among its options. Studies of partition at that time had generally suggested that it should be excluded for practical reasons, notably the very large transfers of population which would be involved. The Turkish Government, faced with Greek demands for Enosis, naturally favoured partition, if there was to be any change in the status quo. The Greeks, however, demanded the union of the whole of Cyprus with Greece, and not merely a part of it. ${ }^{22}$

Being particularly alarmed by the proposals providing for Makarios's return, Anglo-Cypriot talks on a constitution, and the immediate abolition of the Emergency, the Turkish Government raised every possible objection to the Foot Plan and the proposals were therefore abandoned. ${ }^{23}$

\section{The "Macmillan Plan" of 19 June 1958}

The "Macmillan Plan", also known as the "British Plan" and the "Partnership Plan", was announced in the House of Commons by the British Prime Minister on 19 June 1958. The most important feature of the plan was the proposal that a representative of the Greek Government and a representative of the Turkish Government would be appointed to co-operate with the British Governor in carrying out the new policy. A new constitution providing for representative government and autonomy would be framed in consultation with representatives of the two island communities and the Greek and Turkish Governments. ${ }^{24}$ The main provisions of the new Constitution were as follows:

a) There would be a separate House of Representatives for each of the two communities, and these Houses would have final legislative authority in communal affairs.

b) Authority for internal administration, other than communal affairs and internal security, would be undertaken by a Council presided over by the Governor and including the

\footnotetext{
${ }^{21}$ FCO51/353/RR5/15, “A History of proposals for a settlement of the Cyprus problem, 1955-1974”, Research Department Memorandum, 14.12.1974.

22 FCO51/353/RR5/15, "A History of proposals for a settlement of the Cyprus problem, 1955-1974", Research Department Memorandum, 14.12.1974. Göktepe, British, p. 60-137.

${ }_{23}$ FCO51/353/RR5/15, "A History of proposals for a settlement of the Cyprus problem, 1955-1974", Research Department Memorandum, 14.12.1974. Sönmezoğlu, Tarafların, p. 15-55.

${ }^{24}$ FCO51/353/RR5/15, “A History of proposals for a settlement of the Cyprus problem, 1955-1974”, Research Department Memorandum, 14.12.1974. Göktepe, British, p. 60-137.
} 
representatives of the Greek and Turkish Governments and six elected Ministers drawn from the House of Representatives, four being Greek Cypriots and two Turkish Cypriots.

c) The Governor, acting after consultation with the representatives of the Greek and Turkish Governments, would have reserve powers to ensure that the interests of both communities were protected.

d) External affairs, defence and internal security would be matters specifically reserved to the Governor, acting after consultation with the representatives of the Greek and Turkish Governments.

e) The representatives of the Greek and Turkish Governments would have the right to require any legislation which they considered to be discriminatory to be reserved for consideration by an impartial tribunal. ${ }^{25}$

The plan provided that "the international status of the island would remain unchanged for seven years" but did not specify what would happen at the end of this period.

Karamanlis rejected this plan on behalf of the Greek Government on 21 June 1958. The Greeks objected to the idea of an equal partnership with Turkey in the administration of an island, $80 \%$ of whose population was Greek-speaking. They also objected to the nature of the proposed administrative and constitutional system, which they considered unworkable and likely to maintain existing tension between the communities. ${ }^{26}$

Naturally, the Greeks resented the 1:2 representations of the Turkish Cypriots in the authority for internal administration, when their representation according to population should have been 1:4. Karamanlis also indicated his willingness for further discussions on the basis of an alternative plan, according to which a permanent settlement would be deferred until a more appropriate time, and a transitory system of self-government would be negotiated between the British Government and the people of Cyprus, in which the Greek Government offered help by mediation. ${ }^{27}$

Turkish reaction to the Macmillan Plan was initially more cautious. The Turkish Government at this point were convinced that partition was the only solution. While the Turks considered that the British idea of partnership and the Turkish idea of partition were not necessarily irreconcilable, they were worried about the vagueness about the future of the island after the seven-year period had ended. They therefore continued to press their demand for partition, to be introduced at the end of the seven-year period. These objections would eventually cause the Turkish Government to reject the plan. ${ }^{28}$

\section{Makarios's Proposal of Independence (22 September 1958)}

After the Macmillan Plan was rejected by both Greece and Turkey, the British Government did not put it aside, as it had done previously. Rather, it stood firmly by its new policy. By the autumn of 1958, the Greek Government had persuaded Makarios that an interim solution that fell short of Enosis was acceptable in principle in order to put off the proposed implementation

\footnotetext{
${ }^{25}$ FCO51/353/RR5/15, “A History of proposals for a settlement of the Cyprus problem, 1955-1974”, Research Department Memorandum, 14.12.1974. See FO371/144739, Annual Report on Turkey for 1958.

${ }^{26}$ FCO51/353/RR5/15, "A History of proposals for a settlement of the Cyprus problem, 1955-1974", Research Department Memorandum, 14.12.1974. See FO371/144739, Annual Report on Turkey for 1958.

${ }_{27}$ FCO51/353/RR5/15, "A History of proposals for a settlement of the Cyprus problem, 1955-1974", Research Department Memorandum, 14.12.1974. See FO371/144739, Annual Report on Turkey for 1958.

${ }_{28}$ FCO51/353/RR5/15, “A History of proposals for a settlement of the Cyprus problem, 1955-1974", Research Department Memorandum, 14.12.1974. Sönmezoğlu, Tarafların, p. 15-55.
} 
of the Macmillan Plan for partnership between Greece and Turkey in the administration of the island. Consequently, it was Makarios himself, with the support of the Greek Government, who proposed the solution of independence with guarantees against partition or Enosis, on 22 September $1958 .^{29}$

According to the Archbishop's new proposal, after a period of self-government Cyprus would become an independent State "linked neither to Greece nor to Turkey". Furthermore the status of independence would be guaranteed by the United Nations (UN) and would not be changed "either by union with Greece, by partition, or by any other way" unless such a change were approved by the UN. The status of independence would not be incompatible with Cyprus's membership of the British Commonwealth. The Turkish Cypriot community were to enjoy full safeguards under Makarios's plan. The Archbishop suggested that the British Government, together with the Cypriot people's representatives, would frame a constitution for internal self-government. This would operate for a fixed period, after which Cyprus would become independent. ${ }^{30}$

The idea of independence was by no means a new one. However, Makarios's proposals came to nothing as a result of the breakdown in negotiations which the British Government was then conducting for a tripartite conference, and because of the British Government's determination to implement its plan. By the end of 1958 the initiative in attempting to obtain a compromise settlement in place of the British Government's plan had been firmly taken over from Makarios by the Greek Government, which was responsible for the approach to the Turkish Foreign Minister that ultimately led to the Zurich Agreement of February 1959, on which the settlement of 1960 was based. ${ }^{31}$

\section{The 1959-60 Cyprus Settlement}

A basic constitutional structure for an independent Republic of Cyprus was conceded between Greece and Turkey at the Zurich Conference in February 1959, and accepted by the British Government and by representatives of the Greek and Turkish Cypriot Communities at the London Conference later in the same month. Both communities were represented at the subsequent negotiations, which resulted in a settlement in August 1960, based on four main documents:

a) The Treaty of Establishment, between the UK, Greece, Turkey and the Republic of Cyprus, defining the extent the territory of the Republic and of UK's sovereign base areas.

b) The Constitution of the Republic of Cyprus incorporate as unalterable basic articles the framework agreed at Zurich and London. The Constitution was drafted by a body on which the Greek and Turkish Governments and the Greek Cypriots and Turkish Cypriots were represented, but the British Government was not.

c) The Treaty of Guarantee, between the UK, Greece, Turkey and Cyprus, by which the last undertook to adhere to the settlement and the three others, undertook to guarantee this. In the event of a breach of the settlement the three countries undertook to consult together, and, if common or concerted action proved impossible, each power reserved the right to take the measures necessary to ensure the provisions of the settlement.

\footnotetext{
${ }^{29}$ FCO51/353/RR5/15, “A History of proposals for a settlement of the Cyprus problem, 1955-1974", Research Department Memorandum, 14.12.1974. Sönmezoğlu, Tarafların, p. 15-55.

30 FCO51/353/RR5/15, "A History of proposals for a settlement of the Cyprus problem, 1955-1974", Research Department Memorandum, 14.12.1974. See FO371/160212, Annual Report on Turkey for 1960.

31 FCO51/353/RR5/15, "A History of proposals for a settlement of the Cyprus problem, 1955-1974", Research Department Memorandum, 14.12.1974. Sönmezoğlu, Tarafların, p. 15-55.
} 
d) The Treaty of Alliance between Greece, Cyprus and Turkey, binding them to co-operate for their common defence and to resist any attack or aggression, direct or indirect, directed against the independence or the territorial integrity of the Republic of Cyprus. (This Treaty was unilaterally abrogated by the Republic of Cyprus on 4 April 1964, as a result of the 1963-64 Crisis in which Turkish actions and statements were claimed by Makarios to be in breach of the Treaty of Alliance). ${ }^{32}$

\section{The Breakdown of the 1960 Settlement}

The main area of conflict between the two communities in the years immediately after the settlement were related to the safeguards accorded to the Turkish Cypriot minority, which were at the heart of the Constitution. The Greek Cypriots maintained that the safeguards for the Turkish Cypriots in the settlement accorded to them a political representation out of proportion with their numbers. ${ }^{33}$ The principal issues arising from the constitutional settlement which aroused tension and mistrust were:

a) The veto power of the Turkish Cypriot Vice-President in respect of the army and foreign affairs (Article 50, basic).

b) The requirement that legislation relating to electoral law amendment, to municipalities or to taxation had to be passed by separate majorities of the Greek and Turkish Cypriots in the House of Representatives, and not by a simple majority (Article 78, para. 2, basic).

c) The 70 to 30 proportion of Greek to Turkish Cypriots in the Civil Service, and the 60 to 40 proportion in the Cyprus army (Articles 123 and 129, both basic).

d) The provision for the establishment of separate municipalities in the five largest towns (Article 173, basic).

e) The provision for the hearing of legal cases by judges of the community involved (Article 159 , basic). ${ }^{34}$

Before three years of independence was over, an impasse was reached over the major constitutional issues outlined above. The threat of paralysis to both central and local government as a result of disagreements over income tax legislation and the separation of municipalities resulted in a growing Greek Cypriot campaign for the revision of the Constitution. $^{35}$

11. Archbishop Makarios's Proposals for the Amendment of the Constitution (30 November 1963)

On 30 November 1963, Archbishop Makarios drafted thirteen Greek Cypriot proposals for constitutional revision and presented them to the Turkish Cypriot Vice-President, Dr. Küçük. The points were as follows:

1) The right of veto of the President and the Vice-President of the Republic to be abandoned (Article 50, basic).

\footnotetext{
32 FCO51/353/RR5/15, “A History of proposals for a settlement of the Cyprus problem, 1955-1974”, Research Department Memorandum, 14.12.1974. Atun, Kibrls, Passim.

33 FCO51/353/RR5/15, "A History of proposals for a settlement of the Cyprus problem, 1955-1974", Research Department Memorandum, 14.12.1974. See FO371/160212, Annual Report on Turkey for 1960.

34 FCO51/353/RR5/15, "A History of proposals for a settlement of the Cyprus problem, 1955-1974", Research Department Memorandum, 14.12.1974. See FO371/160212, Annual Report on Turkey for 1960.

35 FCO51/353/RR5/15, “A History of proposals for a settlement of the Cyprus problem, 1955-1974", Research Department Memorandum, 14.12.1974.
} 
2) The Vice-President of the Republic to deputise for the President of the Republic in case of his temporary absence or incapacity to perform his duties (Article 36, basic)

3) The Greek President of the House of Representatives and the Turkish Vice-President to be elected by the House as a whole and not as at present the President by the Greek members of the House and the Vice-President by the Turkish members of the House (Article 72).

4) The Vice-President of the House of Representatives to deputise for the President of the House in case of his temporary absence or incapacity to perform his duties (Article 72).

5) The constitutional provisions regarding separate majorities for enactment of certain laws by the House of Representatives to be abolished (Article 78, basic).

6) United municipalities to be established (Article 173, basic).

7) The administration of justice to be unified (Article 159, basic).

8) The division of the security forces into police and gendarmerie to be abolished (Article 130, basic).

9) The numerical strength of the security forces and the defence forces to be determined by law (Articles 129 and 130, both basic).

10) The proportion of the participation of Greek and Turkish Cypriots in the composition of the public service and the forces of the Republic to be modified in proportion to the ratio in the population of Greek and Turkish Cypriots (Articles 123 and 129, both basic).

11) The number of the members of the Public Service Commission to be reduced from ten to five (Article 124).

12) All decisions of the Public Service Commission to be taken by simple majority (Article $125)$.

13) The Greek Communal Chamber to be abolished. This step would have involved extensive amendment of the Constitution. ${ }^{36}$

On 7 December 1963 the Turkish Government, which had also been provided by Archbishop Makarios with a copy of his proposals "for information", categorically rejected the 13 points and insisted on the inviolability of the Constitution. Their response was communicated before the Turkish Cypriot community had replied to the memorandum. The resulting deadlock was broken by the outbreak of serious fighting between the two communities on 23 December 1963, and the collapse of the system of combined Greek and Turkish administration established by the Constitution. The Turkish Cypriots completely withdrew from participation in the central administration and on 28 December 1967 formalised this partition by setting up their own Turkish Cypriot Administration, headed by the Vice President of the Republic. ${ }^{37}$

\section{The London Conference (January 1964)}

In January 1964, the Commonwealth Secretary Duncan Sandys organised a conference in London of representatives of Britain, Greece, Turkey, and both Cypriot communities under his chairmanship, in an attempt to find a solution to the constitutional breakdown in Cyprus. The

\footnotetext{
${ }^{36}$ FCO51/353/RR5/15, “A History of proposals for a settlement of the Cyprus problem, 1955-1974”, Research Department Memorandum, 14.12.1974. Sönmezoğlu, Tarafların, p. 176.

37 FCO51/353/RR5/15, "A History of proposals for a settlement of the Cyprus problem, 1955-1974", Research Department Memorandum, 14.12.1974.
} 
conference ended in deadlock two weeks later, because the views of the Greek and Turkish Cypriots proved to be irreconcilable. ${ }^{38}$

The Greek Cypriots insisted on the continuation of Cyprus as an independent state, and on the cancellation of the Treaties of Guarantee and Alliance, which they considered to be inconsistent with their independence and an insuperable barrier to urgently needed constitutional amendment. They argued that the constitution should be amended so as to include safeguards for the Turkish Cypriot minority proportional to their numbers, and so as to deprive them of their power of making effective government impossible. ${ }^{39}$

The Turkish Cypriots argued for the retention of the Treaties of Guarantee and Alliance, as the only real safeguards of their minority rights, and as a check upon abuses by the Greek Cypriots of their majority status. They demanded an augmentation rather than a diminution of their constitutional rights, given the recent crisis and fighting. They suggested the establishment of a federal system that would imply territorial separation of the two ethnic groups. ${ }^{40}$

\section{The Acheson Plan (July 1964)}

On 4 March 1964, with the looming threat of a Turkish invasion of Cyprus, the UN Security Council recommended the establishment in Cyprus of a UN peacekeeping force (UNFICYP) and the designation by the Secretary General of a mediator, for the purpose of promoting a peaceful and agreed settlement of the Cyprus issue. Tuomioja, the first UN mediator, achieved little success, but his mediation provided a valuable guise under which the U.S. Secretary of State, Dean Acheson, was able to undertake negotiations with representatives of Greece and Turkey in Geneva in July and August $1964 .{ }^{41}$ Acheson presented to the Greeks and Turks for negotiation a series of proposals on the following lines:

a) Cyprus to become part of Greece (Enosis).

b) Greece to permit Turkey to establish a military base in Cyprus on the Karpas peninsula in the north-east of the island.

c) Greece to cede to Turkey the small island of Castelloriso, off the south coast of Turkey.

d) Two "cantons" under Turkish Cypriot administration to be formed.

e) Greece to guarantee the minority rights of the Turkish Cypriots in Cyprus and, if required, to permit United Nations guarantee or supervision of those rights.

f) Compensation to be paid to Turkish Cypriots who might wish to leave Cyprus. ${ }^{42}$

\footnotetext{
${ }^{38}$ FCO51/353/RR5/15, “A History of proposals for a settlement of the Cyprus problem, 1955-1974”, Research Department Memorandum, 14.12.1974. Göktepe, British, p. 144-182. See FO371/180150, Annual Political Report for Turkey, 1964.

39 FCO51/353/RR5/15, “A History of proposals for a settlement of the Cyprus problem, 1955-1974”, Research Department Memorandum, 14.12.1974. Göktepe, British, p. 144-182. See FO371/180150, Annual Political Report for Turkey, 1964.

${ }^{40}$ FCO51/353/RR5/15, “A History of proposals for a settlement of the Cyprus problem, 1955-1974”, Research Department Memorandum, 14.12.1974. Göktepe, British, p. 144-182. See FO371/180150, Annual Political Report for Turkey, 1964.

${ }^{41}$ FCO51/353/RR5/15, “A History of proposals for a settlement of the Cyprus problem, 1955-1974”, Research Department Memorandum, 14.12.1974. Göktepe, British, p. 166-1169. See FO371/180150, Annual Political Report for Turkey, 1964.

${ }^{42}$ FCO51/353/RR5/15, “A History of proposals for a settlement of the Cyprus problem, 1955-1974", Research Department Memorandum, 14.12.1974. Atun, Klbrls, Passim.
} 
The Turkish Government came to the point of being prepared to talk about proposal: (a) provided that there could be a satisfactory arrangement on proposal; and (b). After asking for more, they eventually demanded approximately three quarters of the Karpas peninsula, to be held in full sovereignty. The Greek Government offered a much smaller area, under a lease of 45-50 years. The impending negotiations broke down at this point. It became clear that the Greeks would be unable to persuade Archbishop Makarios and the Greek Cypriots to accept a settlement on the lines proposed, and it was significant that the Cypriots, much to their indignation, had been left completely and deliberately out of these exchanges. Makarios had stated publicly that he would not accept any agreed solution to which the Cypriots were not a party, and when the main idea of Acheson's plans was leaked he stated at a press conference on 30 July that a plan such as that which Acheson was promoting was totally unacceptable. The death of the mediator and the outbreak of fighting at Kokkina on August 5 (believed by some to have been contrived by the Archbishop without the knowledge of the Greek Government in order to sabotage negotiations) contributed to the breakdown of the Geneva negotiations. ${ }^{43}$

\section{The Galo Plaza Report (26 March 1965)}

Sefior Galo Plaza, the United Nations mediator who succeeded Tuomioja, held three rounds of consultations with the parties involved in the Cyprus dispute; and. submitted his report to U Thant on 26 March $1965 .{ }^{44} \mathrm{He}$ made no formal proposals but made it clear that his views were as follows:

a) Cyprus should remain a sovereign, independent state.

b) The Cyprus government should refrain from placing before the Cyprus population the opportunity to opt for Enosis, for as long as there was a danger of hostilities as a result of such a decision. This effectively ruled out Enosis for a considerable period of time.

c) A demilitarisation of the island was suggested, implying a reconsideration of the status of the British military bases.

d) Cyprus should not be separated into two ethnic groups, nor should autonomous Greek and Turkish Cypriot states be created. The Turkish Cypriot minority should, however, be protected by ironclad guarantees and human and individual rights should be backed up by a United Nations Commission in Cyprus.

e) The Turkish Cypriots should enjoy special rights in Cypriot institutions, although these should be less than those they possessed under the 1960 Constitution.

f) The settlement should be guaranteed by the United Nations, through a General Assembly Resolution and the Security Council. ${ }^{45}$

Clearly, the report of Galo Plaza approximated much more closely to the Greeks' than to the Turks' point of view, and it had a sympathetic hearing in Athens and Nicosia.

The Governments of Greece and Cyprus did, however, refuse to consider any restraint in exercising their right of self-determination that would exclude Enosis. The Turkish Government rejected the report without any thought because it favoured the kind of unitary

\footnotetext{
43 FCO51/353/RR5/15, “A History of proposals for a settlement of the Cyprus problem, 1955-1974”, Research Department Memorandum, 14.12.1974. Göktepe, British, p. 144-182.

${ }^{44}$ FCO51/353/RR5/15, “A History of proposals for a settlement of the Cyprus problem, 1955-1974”, Research Department Memorandum, 14.12.1974. Göktepe, British, p. 144-182. See FO371/185824, Turkey: Annual Review for 1965.

${ }^{45}$ FCO51/353/RR5/15, “A History of proposals for a settlement of the Cyprus problem, 1955-1974”, Research Department Memorandum, 14.12.1974. See FO371/185824, Turkey: Annual Review for 1965.
} 
State with minority rights for the Turkish Cypriots advocated by President Makarios. It accused the mediator of having exceeded his terms of reference, and acting rather as an "arbitrator", writing his own views into his report and not seeking to get agreement from the parties concerned. ${ }^{46}$

\section{Greco-Turkish "Dialogue” (May 1966 - September 1967)}

During bilateral talks begun after the NATO meeting in London in May 1965 the Turkish Government raised with the Greek Government the possibility of a solution to the Cyprus problem based upon Enosis with territorial compensation for Turkey, but the Greek Government, weakened by domestic crisis was unable to respond. These exchanges were cut short by the fall of the Greek Government. ${ }^{47}$

In May 1966, the Greek and Turkish Governments began a series of clandestine exchanges on the relations between their two countries, with particular reference to the Cyprus issues. These talks, which were carried out with unprecedented discretion, were known as the "dialogue", and were based on the questionable assumption that any settlement they reached could be imposed on Cyprus. Archbishop Makarios did not publicly oppose these contacts, but he did all he could behind the scenes to ruin the chances of agreement, viewing the dialogue essentially as an attempt to solve the Cyprus problem without his consent or that of the Greek Cypriot majority. ${ }^{48}$

The dialogue was based largely on personal confidence between the Greek and Turkish Foreign Ministers. It is not known exactly what point the dialogue had reached by December 1966 when the fall of the Stephanopoulos Government in Greece brought the talks to an end temporarily. It seems that, while some progress had been made on some of the administrative arrangements that would accompany any solution, the two sides had not dealt with the main issue, namely the ultimate status of the island. It seems clear also that there had been at least discussion on a hypothetical basis about a solution which would include Enosis, with territorial compensation for the Turks (possibly in the form of a Turkish Base in Cyprus). The Greeks seem to have been misled into thinking that Turkey would accept Enosis on terms. ${ }^{49}$

Following the Greek military coup of 21 April 1967 talks with the Turkish Government restarted, and for a time it seemed that some progress was being made. The Cyprus Government was in disagreement with the main Greek proposal in these talks for obtaining Enosis by conceding a degree of Turkish Cypriot self-government and a base in Cyprus for Turkey, and there was tension with the Greek Government over this during the summer of 1967. The Greek talks with Turkey culminated in a meeting between the Greek and Turkish Prime Ministers on 9 and 10 September 1967. At this meeting the Greeks seem to have had the impression that the Turks would be prepared to negotiate on the basis of Enosis, and that negotiations would therefore centre on what compensation would be acceptable to the Turks. The Turks, however, thought they had already made clear that Enosis was not a suitable basis

\footnotetext{
46 FCO51/353/RR5/15, “A History of proposals for a settlement of the Cyprus problem, 1955-1974”, Research Department Memorandum, 14.12.1974. See FO371/185824, Turkey: Annual Review for 1965.

47 FCO51/353/RR5/15, “A History of proposals for a settlement of the Cyprus problem, 1955-1974”, Research Department Memorandum, 14.12.1974. Hande Erol, Lider Rauf Denktaş ve Kıbrıs, Deli Dumrul Kitap, Ankara, 2017, p. 35-100.

${ }^{48}$ FCO51/353/RR5/15, “A History of proposals for a settlement of the Cyprus problem, 1955-1974”, Research Department Memorandum, 14.12.1974. Oran, Türk Dış Politikası, p. 718-749.

49 FCO51/353/RR5/15, “A History of proposals for a settlement of the Cyprus problem, 1955-1974”, Research Department Memorandum, 14.12.1974. George Lenczowski, The Middle East in World Affair, Cornell University Press, New York, 1990, p. 160-166.
} 
for settlement at all. Consequently no agreement was reached and the dialogue was suspended. ${ }^{50}$

\section{The Intercommunal Talks (1968 - 1974)}

Following the 1967 crisis in Cyprus, attempts to reach a settlement on the future constitutional arrangements within the island were conducted by the two communities in Cyprus, according to Makarios's wishes, rather than through bilateral talks between Greece and Turkey. Intercommunal talks started in June 1968 and continued on and off until $1974 .{ }^{51}$

\section{Conclusion}

The Cyprus issue was a prominent feature from many aspects in British, Turkish and Greek foreign policy from 1954 to 1974. Specifically, between the years of 1954 and 1960 there were intensive negotiations on the matter, particularly in 1958 and 1959. The period from February 1959 to August 1960 can be regarded as a transition period, during which the Zurich-London Agreements began in February 1959 and lasted until the formation of the new state of Cyprus on 16 August 1960. The result was that Cyprus gained independence under the guarantees of Britain, Turkey and Greece.

In spite of these events, strained relations between the Greek and Turkish Cypriot communities continued, with inter-communal violence breaking out in December 1963. The government collapsed when fighting erupted on 21 December 1963, the main reason being the lack of security for the Turkish community. Thus, the Constitution of the Republic of Cyprus had been breached. Consequently, the Greek Cypriots and their leader, Makarios, insisted on amending the Constitution to the benefit of the Greek Cypriot community, their aim being to abrogate the Zurich-London Agreements, which they claimed gave more rights to the Turkish community than was justified by the size of their population. Moreover, they regarded the Constitution and the Agreements as a hindrance to Enosis. On 30 November 1963, Makarios presented his 13-point proposal to the Turkish Cypriots and to the three guarantor states, Britain, Turkey and Greece. However, it was rejected by the Cypriot Turkish community and officially by the Turkish government on 6 December 1963. On 30 December 1963 Makarios declared that coexistence between the communities was impossible and "disastrous".

In this way, the Cyprus problem had become one of great international importance for the British. It involved Britain's own strategic interest, specifically those of NATO and CENTO, and even general world peace. The British government saw that they had to intervene to stop the violence before it grew into a full-blown Greco-Turkish war, which would weaken NATO's south-eastern flank against the communist bloc. Given this situation, the British government summoned a conference in London in January 1964 to find a solution to the Cyprus problem with the other guaranteeing powers and the two island communities. No settlement was reached, mainly because of a conflict in interest of both parties. Ultimately, a United Nations peace-keeping force for Cyprus was established in March 1964, which served to lessen the tension between the communities in Cyprus. It did not, however, put an end to the struggle.

\footnotetext{
${ }^{50}$ FCO51/353/RR5/15, “A History of proposals for a settlement of the Cyprus problem, 1955-1974”, Research Department Memorandum, 14.12.1974.

51 FCO51/353/RR5/15, “A History of proposals for a settlement of the Cyprus problem, 1955-1974”, Research Department Memorandum, 14.12.1974. Erol Mütercimler, Satılık Ada Kıbrls, Alfa Yayınları, İstanbul, 2017, p. 109205. Oran, Türk Dış Politikası, p. 718-749. For more information on intercommunal talks, see Yasin Coşkun, "The Beginning of a New Era in the Cyprus Problem after the 1967 Crisis: The Inter-Communal Talks", History Studies, Volume: 10, Issue: 9, (December 2018), pp. 55-84.
} 
In the period from 1963 to 1974, there were several proposals suggested for a settlement of the Cyprus issue. Although Britain and the United States were in favour of Enosis rather than independence, they realised that they could not hope for a solution without Turkey's acceptance. Hence, they thought Turkey should be offered some compensation for Enosis, which might involve a base in Cyprus, or cantons for the Turkish community. The Turkish government seemed to be flexible regarding this proposal. While the Greek side would have been satisfied with any solution that brought about Enosis, they were reluctant to give any territory to Turkey.

The Cyprus problem affected Turkey's foreign policy, particularly with Britain and the Unites States, and accelerated closer ties between the Turks and the Soviets. Although the Turkish government expected a more active policy from Britain, it followed a wait-and-see policy. Britain did not want to take an active role in the Cyprus issue, so the United States became involved instead. The United States did not give any great support for Turkey's proposals, so the Cyprus issue became the most important factor in Anglo-Turkish and TurcoAmerican relations. Even though each country sometimes faced difficulties in maintaining close relations, they all agreed on the need to maintain sincere relations as joint members of the NATO and CENTO alliances. They all knew that during the Cold War period they should not cause the south-eastern flak of NATO against the Soviets. Under these circumstances, Britain wanted to maintain close relations with Turkey, while at the same time wanted to avoid any strain in relations with Greece and the Cypriots over its bases on the island.

Finally, the period 1954-1974 was one of intensive action both regarding the Cyprus issue and in Anglo-Turkish and Turco-American relations. By the middle of 1974 there appeared to be no workable solution, only disadvantages for the Turkish Cypriots and Turkey. Greece and the Greek Cypriots, on the other hand, strengthened their authority on both internal and international levels.

\section{Bibliography}

\subsection{Archival sources}

All references to sources prefixed by FCO and FO refer to documents held at the UK National Archives (TNA), formerly the Public Record Office (PRO). The following files have been consulted: FCO51/353/RR5/15; Annual Reports on Turkey (1954-1974):

FCO9/1091, Turkey: Annual Review for 1968.

FCO9/1308, Turkey: Annual Review for 1969.

FCO9/1466, Turkey: Annual Review for 1970.

FCO9/1606, Turkey: Annual Review for 1971.

FCO9/1831, Turkey: Annual Review for 1972.

FCO9/2112, Turkey: Annual Review for 1973.

FCO9/2339, Turkey: Annual Review for 1974.

FCO9/614, Turkey: Annual Review for 1967.

FCO9/RK1011/1, Turkey: Annual Review for 1954. 
FO371/123999, Annual Review for 1955.

FO371/130174, Turkey: Annual Review for 1956.

FO371/136450, Annual Report on Turkey for 1957.

FO371/144739, Annual Report on Turkey for 1958.

FO371/153030, Annual Political Review for Turkey 1959.

FO371/160212, Annual Report on Turkey for 1960.

FO371/163832, Annual Report on Turkey for 1961.

FO371/169514, Annual Review of Turkey for 1962.

FO371/174971, Annual Review for Turkey for 1963.

FO371/180150, Annual Political Report for Turkey, 1964.

FO371/185824, Turkey: Annual Review for 1965.

FO371/185824, Turkey: Annual Review for 1966.

\subsection{Books \& Articles}

ALASYA, Fikret, Kuzey Kıbrls Türk Cumhuriyeti Tarihi, Ankara, 1987.

ALASYA, Fikret, The Republic of Cyprus and the events that have come to pass: The Aim and the Attitude of the Greeks, Ayy1ldız Matbas1, Ankara 1969.

ATUN, Ata, Kıbrıs Anlaşmaları, Planları ve Önemli BM, AB Kararları (1571-1983), Cilt: I, Samtay Vakfı Yayınları, Mağusa, 2007.

BABAOĞLU, Resul, “Türkiye'nin Kıbrıs Politikasının Evriminde Bir Dönüm Noktası: Londra Konferansı (29 Ağustos-6 Eylül 1955)", Çağdaş Türkiye Tarihi Araştırmaları Dergisi, Cilt: 18, Say1: 36, (Bahar 2018), pp. 323-347.

COŞKUN, Yasin, "The Beginning of a New Era in the Cyprus Problem after the 1967 Crisis: The Inter-Communal Talks", History Studies, Volume: 10, Issue: 9, (December 2018), pp. 55-84.

COULOUMBIS, Theodore A., The United States, Greece and Turkey: The Troubled Triangle, Praeger, New York 1983.

EHRLICH, Thomas, Cyprus, 1958-1967, Oxford University Press, Oxford, 1974.

EROL, Hande, Lider Rauf Denktaş ve Kıbrls, Delidumrul Kitap, Ankara, 2017.

ERTEKÜN, Necati M. The Cyprus Dispute and the Birth of the Turkish Republic of Northern Cyprus, (2nd ed.), K. Rustem \& Brothers, Nicosia 1984.

FIRAT, Melek, 1960-71 Arası Türk Dış Politikası ve Kıbrıs Sorunu, Siyasal Kitabevi, Ankara 1997.

GAZIOĞLU, Ahmet C., Two Equal and Sovereign Peoples: A Documented Background to the Cyprus Problem and the Concept of Partnership, Cyrep, Nicosia, 1997.

\section{History Studies}


GÖKTEPE, Cihat, "The Cyprus Crisis of 1967 and its Effects on Turkey's Foreign Relations”, Middle Eastern Studies, Vol.: 41, No: 3, 2005, pp. 431-444.

GÖKTEPE, Cihat, British Foreign Policy towards Turkey, 1959-1965, Frank Cass, London, 2003.

GÜREL, Şükrü Sina, Kıbrls Tarihi (1878-1960): Kolonyalizm, Ulusçuluk ve Uluslararası Politika, Kaynak Yayınları, İstanbul, 1995.

HASGÜLER, Mehmet, "Uluslararası Politikada Kıbrıs Sorunu: 1950-1958”, Tarih ve Toplum, (Temmuz 1999), Say1: 187, s. 17-23.

HASGÜLER, Mehmet, Kıbrıs'ta Enosis ve Taksim Politikalarının Sonu, Alfa Yayınları, İstanbul, 2007.

KOUMOULIDES, J. T. A. (ed.), Cyprus in Transition, 1960-1985, Trigraph, London, 1986.

LENCZOWSKI, George, The Middle East in World Affair, Cornell University Press, New York, 1990.

MÜTERCIMLER, Erol, Satılık Ada Kıbrıs, Alfa Yayınları, İstanbul, 2017.

ORAN, Baskın (ed.), Türk Dış Politikası, Cilt-I: 1919-1980, İletişim Yayınları, İstanbul, 2003.

SÖNMEZOĞLU, Faruk, Tarafların Tutum ve Tezleri Açısından Kıbrıs Sorunu (1945-1986), İÜ İktisat Fakültesi Yayınları, İstanbul, 1991.

SONYEL, Salahi R., Cyprus: The Destruction of a Republic; British Documents 1960-65, Eothen Press, Huntingdon, 1997.

SONYEL, Salahi R., Why did The Inter-Communal Talks on Cyprus (1968-71) Fail? Revelations in the light of British Official Documents released recently, Cyrep, Lefkoşa, 2000. 